\title{
Company disclosures concerning the resilience of cities from the Sustainable Development Goals (SDGs) perspective
}

\author{
Diletta Acuti, University of Porstmouth \\ Marco Bellucci, University of Florence \\ Giacomo Manetti, University of Florence
}

\begin{abstract}
Although companies are decisive in contributing to urban resilience, unresolved questions remain about what practices they can implement. Considering that the concept of resilience is acknowledged both explicitly and implicitly in a range of Sustainable Development Goals (SDGs), this research aims to fill the existing gap between theoretical considerations about the role of companies in fostering urban resilience and the practices they implement and disclose. On the one hand, we build a theoretical framework based on strategic and instrumental components that can support the contribution of companies to urban resilience. On the other hand, we analyze 138 sustainability reports of organizations operating in Italy and Japan to identify how the SDGs, with particular reference to those targets concerning environmental and social resilience, are implemented in their activities and communicated in their nonfinancial reports. Since greater attention to disclosures on the impacts of companies on resilience is a starting point for action towards achieving the SDGs, this study provides new insights into the contribution of companies to the resilience of cities, advancing the literature on the link between business and urban resilience.
\end{abstract}

\section{Keywords}

Urban resilience, SDGs, sustainability reporting, cities, content analysis, GRI

\section{Introduction}

The idea of urban resilience has evolved to span many academic debates, and it has begun to infiltrate a host of additional, more loosely connected social and economic policies related to security, risk and vulnerability across the developed and developing worlds (Coaffe, 2013). In the most recent iteration of the global sustainable development agenda, Transforming Our World: The 2030 Agenda for Sustainable Development, the United Nations (UN) adopted seventeen Sustainable Development Goals (SDGs) that are intended to "stimulate action over the next 15 years in areas of critical importance for humanity and the planet" (United Nations, 2015, p. 3; Bebbington and Unerman, 2018). These goals follow the 15-year Millennium Development Goals (MDGs) period, defined by Bill Gates as "a type of global report card for the fight against poverty for the 15 years from 2000 to 2015" (Sachs, 2012, 2206). However, the SDGs were designed differently from the MDGs in many ways, in that the aim was to be more inclusive with regard to a number of stakeholders at several levels of governance (Gellers, 2016).

The SDG framework recognizes that government action alone cannot achieve the SDG targets, as doing so will require concerted action across governments, public and private sector organizations, civil society and individual citizens. Indeed, the SDG agenda calls for a global partnership at all levels between all countries and stakeholders; collaboration is necessary to achieve the goals, and such collaboration includes a broad spectrum of actors such as companies, local governments, national and international bodies and civil society organizations (Caiado et al., 2018; Sharifi and Yamagata, 2016). 
Since pursuing resilience through inclusive planning and engaging with communities through narratives reveals the symbolic meaning of resilience (Goldstein et al., 2013), we aim to deepen the operationalization of resilience as an SDG that includes the action of both institutions and companies. In particular, this study builds on Jabareen (2013) and Ahern (2003) to contribute to the understanding of the role of companies in the resilience of cities and urban regions from the SDG perspective. Although the literature provides guidance on which strategies can foster resilience (Ahern, 2003) and which instruments are useful in implementing these strategies (Jabareen, 2013), the role of companies in achieving urban resilience is still unclear. Despite an increase in studies about resilience in the urban setting, the majority of scholarship that addresses this topic fails to offer a comprehensive identification of the companies' activities toward resilience and often covers only a limited aspect of the phenomenon. This research contributes to filling the existing gap between theoretical considerations about the role of companies in fostering urban resilience and the practices they implement and disclose. Because of this lack of knowledge, we aim to analyze companies' non-financial disclosure to understand their practical contribution to urban resilience. We opted for a qualitative methodology built on a content analysis of social, economic, and sustainability (SES) reports realized in accordance with the GRI standard for sustainability reporting, which represents the most commonly used international standard for the preparation of SES reports (Thorne et al., 2014; Bellucci et al., 2019; Diouf and Boiral, 2017), as more than 13,000 organizations from more than 80 countries currently use (or have used) GRI guidelines to produce their sustainability reports (Global Reporting Initiative, 2016).

Resilience connotes the capability of systems - such as cities and regions - to withstand a shock and adapt to it by gradually returning to the normal state or by evolving into a better state (Acuti and Bellucci, 2019). In recent years, the popularity of resilience has become a mainstream topic in both academic and policy discourse (Brown, 2014; Normandin and Therrien, 2016). In particular, this word has emerged as an appealing perspective on cities, which are often theorized as highly complex, adaptive systems (Meerow et al., 2016). The etymological roots of "resilience" stem from the Latin word resilire, which means "to bounce back," and the word refers to the ability of an organism or system to recover a position after a disturbance (Klein et al., 2003; Oliva and Lazzeretti, 2017). Hudson (2010, p.12) defines resilience as "the capacity of ecosystems, individuals, organizations or materials to cope with disruption and stress and retain or subsequently regain functional capacity and form".

In the context of cities and urban regions, the concept of resilience emerged in the 1990s in response to contemporary environmental and social threats, and it generally refers to the ability to absorb, adapt, and respond to changes in an urban system (Desouza and Flanery, 2013; Pizzo, 2015). Cumming (2011) cites the contemporary definition of Carpenter, Walker, Anderies, and Abel (2001), i.e., consisting "of (1) the amount of disturbance that a system can absorb while still remaining within the same state or domain of attraction; (2) the degree to which the system is capable of self-organization (versus lack of organization or organization forced by external factors); and (3) the degree to which the system can build and increase its capacity for learning and adaptation". These three levels reflect systemic integrity, coordination, and selfimprovement in relation to local conditions, and they are all dependent on functional networks, or connecting and signaling components, in a local environment (Desouza and Flanery, 2013). Although resilience shares much with other key contemporary urban goals, such as good governance and sustainable development, it also has many peculiarities. A resilient city is a sustainable network of physical systems and human communities that is built for strength and flexibility, rather than brittleness and fragility (Godschalk, 2003). The Rockefeller Foundation, a private foundation dedicated to helping cities around the world become more resilient to this century's environmental, social, and economic challenges, defines resilience as "the capacity of individuals, communities, institutions, businesses, and systems within a city to survive, adapt, 
and grow no matter what kinds of chronic stresses and acute shocks they experience" (100 Resilient Cities, 2018). Since cities are increasingly understood as driving forces for reducing global environmental change and as facilitators of a more sustainable development worldwide, resilience has been stimulated and supported by numerous international institutions. Therefore, to support long-term urban sustainability, broader development policies and plans should be combined with urban and regional efforts to promote resilience.

The remainder of this article is structured as follows. Section 2 explores the SDGs and their connections with the concept of resilience. Section 3 expands our theoretical framework with an analysis of strategic and instrumental components that can support the resilience planning. Section 4 illustrates our methodology based on a qualitative content analysis of 138 Global Reporting Initiative (GRI) sustainability reports prepared by Italian and Japanese organizations. Section 5 presents our main findings on the role and disclosures of companies regarding urban resilience from the SDG perspective. Section 6 summarizes our main contributions and provides a set of practical implications for companies and policymakers.

\section{Resilience in the SDG framework}

The concept of resilience is acknowledged both explicitly and implicitly in a range of SDG targets (Bahadur et al., 2015). Target 1.5 represents one of the core resilience targets: "By 2030 build the resilience of the poor and those in vulnerable situations, and reduce their exposure and vulnerability to climate-related extreme events and other economic, social and environmental shocks and disasters". In addition, resilience is a core feature of target 13.1 in its aim to "strengthen resilience and adaptive capacity to climate-related hazards and natural disasters in all countries" and, as discussed in Bahadur et al. (2015), underpins the achievement of several other targets, including:

- Target 2.4: "By 2030 ensure sustainable food production systems and implement resilient agricultural practices that increase productivity and production, that help maintain ecosystems, that strengthen capacity for adaptation to climate change, extreme weather, drought, flooding and other disasters, and that progressively improve land and soil quality";

- Target 9.1: "Develop quality, reliable, sustainable and resilient infrastructure, including regional and trans- border infrastructure, to support economic development and human well-being, with a focus on affordable and equitable access for all";

- Target 9.a: "Facilitate sustainable and resilient infrastructure development in developing countries through enhanced financial, technological and technical support to African countries, LDCs, LLDCs and SIDS";

- Target 11.5: "By 2030, significantly reduce the number of deaths and the number of people affected and substantially decrease the direct economic losses relative to global gross domestic product caused by disasters, including water-related disasters, with a focus on protecting the poor and people in vulnerable situations";

- Target 11.b: "By 2020, substantially increase the number of cities and human settlements adopting and implementing integrated policies and plans towards inclusion, resource efficiency, mitigation and adaptation to climate change, resilience to disasters, and develop and implement, in line with the Sendai Framework for Disaster Risk Reduction 2015-2030, holistic disaster risk management at all levels";

- Target 11.c: "Support least developed countries, including through financial and technical assistance, for sustainable and resilient buildings utilizing local materials"; 
- Target 14.2: "By 2020, sustainably manage, and protect marine and coastal ecosystems to avoid significant adverse impacts, including by strengthening their resilience and take action for their restoration, to achieve healthy and productive oceans".

Climate change is one of the many types of shocks and stresses that cities and regions face, and climate change-related shocks typically occur together with other environmental, economic, and political stresses (Leichenko, 2011). Awareness of the enormous risk associated with climate change is increasing globally. The year 2016 set the record - for the third consecutive year - for the warmest year on record globally; it also set the record for the lowest levels of sea ice in the Arctic region since satellite monitoring began (Munich RE, 2017a). Due to the devastating effect of climate change, the 2017 Global Forum on Urban Resilience and Adaptation shed light on the recent catastrophes that were caused by this phenomenon and its influence on the resilience of cities and regions. According to the latest sigma study (Swiss RE, 2017), in 2016, 327 disaster events were recorded, of which 191 were natural disasters, such as earthquakes (Oliva and Lazzeretti, 2018), floods, tropical storms, and wildfires. These events can have a particularly devastating and lasting impact on cities and regions in developing countries, thereby setting back the development progress and compromising the wellbeing of present and future generations.

For these reasons, the effort to identify and assess hazard risks, reduce vulnerability and exposure, and increase resistance, adaptive capacity, and emergency preparedness to build resilience is actually fundamental (Koch and Ahmad, 2018; Ciani et al., 2016). The SDGs play a crucial role in this process because they emphasize how important it is for cities to deal with climate change and contain or reduce its consequences, thereby clarifying targets and indicators for inclusive, safe, resilient, and sustainable cities and regions. Moreover, the resilience of cities and regions is important for the implementation of other SDGs. Meerow, Newell, and Stults (2016) explain how estimates based on the wording of the zero draft of the SDGs indicate that $21 \%$ of the 169 targets of all 17 SDGs can be implemented only with urban stakeholders, 24\% should be implemented with urban stakeholders, and a further $20 \%$ should have a much clearer orientation towards urban stakeholders, although current wording does not suggest this level of importance of these stakeholders.

Resilience is often associated with the word "sustainable." Although the two words differ in many respects, rational urban development can be achieved only when it is both resilient and sustainable. Urban planners, policymakers, and researchers should pay equal attention to both resilience and sustainability in decision-making (Zhang and $\mathrm{Li}, 2018$ ). During the last two decades, metropolitan areas around the world have been engaged in a multitude of initiatives aimed at upgrading urban infrastructure and services to create better environmental, social, and economic conditions and enhance the attractiveness and competitiveness of cities and local regions (De Jong et al., 2015; Biggeri et al., 2017). Reflecting these developments, many new categories of "cities" have entered the policy discourse: "sustainable cities," "resilient cities," "green cities," "digital cities," "smart cities," "intelligent cities," "knowledge cities," and "eco cities" (De Jong et al., 2015). Although it often appears as though policymakers, planners, and developers use these words interchangeably, each of them embodies distinct conceptual perspectives, which have implications for how they are theoretically understood and applied in policy (De Jong et al., 2015).

By orienting their corporate social responsibility (CSR) activities towards the needs of their communities, companies can significantly contribute to the resilience of cities and regions. Moreover, social enterprises, cross-sector partnerships and third-sector organizations are increasingly seen as effective and sustainable practices for tackling the social and environmental concerns of communities and improving their multidimensional resilience (Testi et al., 2017; Biggeri et al., 2017). The SDGs strictly recommend the collaboration of different actors for resilience and sustainability. SDG \#17 suggests that companies should "enhance the 
Global Partnership for Sustainable Development, complemented by multi-stakeholder partnerships that mobilize and share knowledge, expertise, technology and financial resources, to support the achievement of the Sustainable Development Goals in all countries, in particular developing countries" (Target 17.16) (The Global Goals, 2019). Thus, innovative relationships forged between governments and businesses are helpful for addressing complex social and ecological problems that are too extensive to be solved by any one organization (Le Ber and Branzei, 2010). Some authors (Milliman and Grosskopf, 2004; Selsky and Parker, 2005) have examined collaboration between states and local businesses and underlined how collaborations can be undertaken to facilitate the development and transfer of new strategies and knowledge for environmental and social performance.

\section{The resilience planning}

The main academic and managerial literature about resilience (Luederitz et al., 2013; Lee, 2014; $\mathrm{Wu}, 2014$; Leitner, 2018) identifies various elements that are relevant for planning resilience. In particular, Ahern (2013) suggests that there are 5 resilience strategies that institutions can implement, and Jabareen (2013) identifies 4 major instrumental components that are useful for fostering resilience. These instrumental components can be adopted by institutions to implement resilience strategies through cross-sector partnerships with companies. Thus, we describe each strategy and instrument, underling the need of companies in intervening as partners for fostering territorial resilience.

\subsection{Resilience strategies}

Cities can implement five strategies to build resilience capacity: a) biodiversity, b) urban ecological networks and connectivity, c) multifunctionality, d) redundancy and modularization, and e) adaptive design (Ahern, 2013). Each strategy can be implemented with the intervention of companies as partners to foster territorial resilience.

A broad range of stakeholders and decision makers recognize biodiversity as an important aspect of city and regional resilience in urban planning. In general, biodiversity refers to the variety of plant and animal life in a particular habitat, a high level of which is usually considered important and desirable. Urban biodiversity can be interpreted in the context of response diversity - "a diversity of species and ecosystems that collectively support specific functions but respond differently to change and disturbance" (Ahern, 2013, p. 1206).

To preserve biodiversity in cities and regions, policymakers should implement strategies to ensure that biodiversity and ecosystem services are effectively protected and managed (Campbell-Arvai, 2018). The key role of the management of corporate biodiversity impacts in resolving environmental crises and improving resilient value, underlined by the GRI, is increasingly being recognized (Rainey et al., 2015). Moreover, recent biological catastrophes such as the damage caused by Monsanto's glyphosate - are a reference point that highlights the grave risks of corporate biodiversity stewardship (Rimmel and Jonäll, 2013).

A suitable approach to improving the resilient value of urban space is urban connectivity, e.g., "the ability to create and maintain a connection between two or more points in a spatial system" (Reggiani et al., 2015, p. 5) that is highly developed for connectivity-dependent functions, including transportation, communication, and energy distribution. Connectivity in urban ecosystems can be achieved through sustainable multifunctional networks, such as greenways, ecological networks, blue-green networks, river ways, and parkways. Connected socioecological systems are believed to provide better ecological functions and to exhibit a higher capacity to survive, adapt and evolve (De Montis et al., 2016). In the specific case of cities as intensively managed systems and as coupling human and natural systems, maintaining 
the connectivity of ecological units is challenging, thus putting at risk the ecological resilience of the system (Olazabal et al., 2018).

Cities can also enhance their resilience through spatial land-use planning. Multifunctionality represents the "deliberate provision of multiple ecosystem services in a discrete area of urban land" (Ahern, 2013, p. 1208), and it is essential to obtain a more efficient use of space in urban planning since space is limited and competed for in all urban environments. According to Lovell and Taylor (2013), multifunctionality is characterized by four primary aspects: (1) the functions interact beyond just shared location, (2) the interactivity is positive and synergistic, (3) the landscape can provide products and services beyond cultural associations, and (4) rural and urban regions are considered together as a continuous matrix. For example, with regard the agri-food sector, in 1998, multifunctionality was adopted as a policy principle by OECD agriculture ministers, recognizing that "beyond its primary function of supplying food and fibre, agriculture can also provide a wide range of environmental benefits, such as recreational amenities and aesthetic values of the rural landscape, non-use values of biodiversity and habitat protection, intrinsic values of ecosystem, watershed, and resource functions" (Hediger, 2008, p. 5). Multifunctionality can also provide socioeconomic benefits, such as food security, food safety, animal welfare, rural employment, the viability of rural areas, and cultural heritage (Pahl-Wostl, 2006).

Resilience applied to urban planning suggests a modular approach that includes redundant and decentralized elements. Modularization implies that system components have enough independence that damage to or the failure of one part or component of a system will, by design, have a low probability of inducing the failure of other similar or related components in the system. Modularization is a way to decrease the complexity of systems by building them from smaller subsystems (or modules) that can be designed independently yet function together as a whole (Peltokorpi et al., 2018, p. 32). Within the urban context, it can be understood as a city's ability to maintain the effective functioning of its key life safety and critical system as a whole - mainly during episodes of intense environmental stress - even if one or more parts of the system are compromised. For example, companies could contribute by making available diverse, decentralized and redundant power plants based on different mixes of sustainable energy sources.

To improve a city or region's resilience, it is necessary to innovate based on the best available knowledge. Various initiatives arise that aim to share ways of becoming more resilient, but on occasion, plans and policies are developed in a context of uncertainty and incomplete knowledge (Acuti and Bellucci, 2019). In this sense, adaptive design is helpful since through adaptive design, it is possible to identify imminent changes to components or conditions and to respond by rebalancing resilience strategies. Indeed, adaptive design represents "an alternative scientific and professional strategy approach in which plans and policies are developed in a context of uncertainty and incomplete knowledge" (Ahern, 2013, p. 1209). From this perspective, companies can improve and share their adaptive capacity, developing innovations that enable organizations to survive under hazards that threaten their existence (SaldañaZorrilla, 2008).

\subsection{Instrumental components}

According to Jabareen (2013), cities, regions and their urban communities can adopt certain instrumental components to move towards a more resilient state in the future: f) vulnerability, g) prevention, h) governance, and i) uncertainty.

In the context of resilience of cities, vulnerability refers to "the inherent susceptibility to harm from exposure to exogenous or endogenous risks" (SDGs, 2019). It represents the degree to which an urban system is likely to experience harm due to exposure to a hazard, either a perturbation or a stress (Berkes, 2007). Companies can reduce the vulnerability of territories by 
implementing a proper risk management program that limits and avoids partial risk and that shares unavoidable risks with other parties (Chen et al., 2012). However, since it is impossible to completely predict the vulnerability of technological and social systems, the ability to accommodate change - and without catastrophic failure - is critical in times of disaster (Godschalk, 2003; Hudec et al., 2018). For example, the Asian Cities Climate Change Resilience Network, established in early 2009 by the Rockefeller Foundation, has helped developing cities reduce the vulnerability of urban areas to climate change by creating local networks with the aim of sharing knowledge (Pinkse and Kolk, 2012).

A city can apply certain preventative actions to prevent hazards, to involve the city's spatial restructuring in preparation for a future environmental disaster, and to seek alternative clean energy. This idea of prevention is included in the concept of resilience itself since it can be interpreted as "the ability to detect, prevent and if necessary handle disruptive challenges" (Coaffee and Wood, 2006, p. 504). Both governmental administration (public) and private organizations should participate in programs (Tsengand Chen, 2012) that are useful to predispose various components that should be considered to contribute to the prevention of environmental hazards and climate change impacts (Jabareen, 2013).

Developing a proper urban governance is crucial for achieving resilience (Bulkeley, 2010). Cities can include different actors in decision-making processes and in the realm of planning, open dialogue, accountability, and collaboration. In the search for greater resilience, it is necessary to include third-sector and nonprofit organizations, social economy actors, social enterprises, and companies that carry out CSR activities.

Thus, achieving resilience requires a collaborative and inclusive governance system. At the same time, since territories are vulnerable to a variety of social or economic shocks and warnings that originate externally, governance has to be adaptive. In a context of contested resources, uncertainty, fragmentation, and interdependence, cities need to ensure the flexibility, timeliness, and learning required for the resilience of our socioecological systems (Booher and Innes, 2010).

Uncertainty-oriented planning is another useful instrumental component for managing risks and improving resilience; unlike conventional planning approaches, it is closely associated with uncertainties to control them. Since uncertainty is linked to actors' limited knowledge, dealing with uncertainty requires specific processes through which actors jointly analyze experiences, build expectations and learn lessons. According to Hutter (2016), public and private actors may decide not only to reduce uncertainty through joint efforts and to learn from past surprises but also to collaborate to prepare for future uncertainties.

Consequently, given that planners must cope with uncertainty, it is necessary to design cities that can effectively handle unexpected contingencies (Godschalk, 2003). Companies could consider further developing their risk management procedures by including the outcomes for their community and by supporting local institutions in defining a detailed risk management strategy.

\section{Methodology}

\subsection{Sample and data}

We deliberately decided to investigate the SES reports produced by organizations operating in Italy and Japan, two countries characterized by the highest level of hydrogeological risk in the world (ISPRA, 2015; Oliva and Lazzaretti, 2017). Since we aim to deepen the operationalization of urban resilience as an SDG that includes the action of both institutions and companies, we are interested in analyzing local settings that are particularly prone to environmental and social shocks. According to the recent study "Hydrogeological instability in Italy: hazard and risk indicators - Report 2015" (ISPRA, 2015), Italy is among the European 
countries most affected by hydrogeological instability. ANCE/CRESME (2012) estimated the costs related to hydrogeological instability (including earthquakes) in Italy to be approximately 3.7 billion euros/year for the period 1944-2013. Additionally, hydrogeological instability is a topic of particular relevance for Japan due to its impacts on the population, linear communication infrastructures and the economic and productive context. Due to its geological, geomorphological and hydrographic conformation, Japan is naturally predisposed to phenomena of instability. While world-class infrastructure and high-tech warning systems mean that the death toll and damage are generally lower here than elsewhere, climate change is putting them to the test (Oliva and Lazzaretti, 2017;2018).

On 1 December 2018, we collected all the SES reports that were disclosed by organizations operating in Italy and Japan and that were published in English and Italian in 2017 on the GRI online database with a minimum level of adherence "In accordance - Core" to the GRI G4 or GRI standards. This selection, which excludes a limited number of reports written in Japanese, resulted in a sample of 138 sustainability reports (93 for Italy, 45 for Japan). Table A in the Appendix illustrates the main characteristics of the included organizations in terms of size, type, presence on the national stock market, and sector. We deliberately decided to include all possible sectors in our analysis to have a clearer idea of the different shapes that the contribution of companies to urban resilience can take. The final sample of organizations is composed of 51 multinational enterprises, 76 large organizations and 11 small and medium-sized enterprises. Eighty of the analyzed reports have external assurance provided by an independent party, and 40 reports explicitly claim to have been prepared from the perspective of the UN SDGs.

\subsection{Content analysis of SES reports}

A qualitative content analysis of the GRI sustainability reports of the companies listed in Table A was performed to identify whether and how these companies disclose their contribution to urban resilience.

Content analysis is a research technique based on the objective, systematic, and quantitative description of the manifest content of communication (Berelson, 1952). According to Bryman and Bell (2015), content analysis has been increasingly used in business research to examine media items and annual reports. Through content analysis, it is possible to distil words into content-related categories (Elo and Kyngäs, 2008). Content analysis is a research method for making replicable and valid inferences from data to their context, with the purpose of providing knowledge, new insights, a representation of facts and a practical guide to action (Krippendorff, 2004). Particularly when researchers - as in our case - want to code text in terms of certain subjects and themes, content analysis allows a categorization of the phenomena of interest (Bellucci and Manetti, 2018).

Qualitative content analysis is defined as a research method for the subjective interpretation of the content of text data through the systematic classification process of coding and identifying themes or patterns (Hsieh \& Shannon, 2005). In particular, we resorted to a deductive content analysis (Kyngas \& Vanhanen, 1999) where the structure of analysis is operationalized on the basis of previous literature - the instrumental components developed by Jabareen (2013) and the strategies discussed by Ahern (2003).

The reliability of the data produced by our content analysis was ensured by using multiple coders and by analyzing discrepancies that emerged between the coders (Milne and Adler, 1999; Guthrie et al., 2004; Manetti and Bellucci, 2016). Given the large size of the sample and the vast amount of text that needed to be processed, the data collection team was composed of two researchers, two supervisors, and one coordinator.

The reports were given unique IDs, and their contents were manually analyzed. A specific data entry grid was developed to support the data collection phase, the coding scheme, and the categorization of concepts. External appendixes or secondary reports were not included in the 
analysis. The research team created specific guidelines based on contents and keywords related to the main concepts discussed in Section 3 of this article to code information. Using the scholarly literature on urban resilience and the SDGs as a guide, we developed our own coding categories, emphasizing the role of companies in resilience, especially the resilience of cities and regions, and the SDGs. The categories used in our content analysis were based on the strategic and instrumental components illustrated in Table 1. Our content analysis collected all paragraphs that met the abovementioned coding scheme and its list of keywords, which enabled us to analyze what companies report about their activities concerning urban resilience and their contribution to SDG goals and targets that specifically concern resilience.

\section{The roles of companies in resilience: empirical evidence from SES reporting}

\subsection{Findings on strategic and instrumental components}

This section illustrates the main findings of our study, with particular reference to the role of collaborations in achieving urban resilience. By analyzing the reports of 138 organizations operating in countries with high hydrogeological risk (i.e. Italy and Japan), we identify how the SDGs are implemented in their activities and are communicated in their nonfinancial disclosures. In particular, we focus on strategic and instrumental components (Jabareen, 2013; Ahern, 2003) to understand whether and how companies contribute to resilience implementation. Table 1 provides an overview of the adoption rate of strategic and instrumental components, segmented for Italy, Japan and the totality of the company included in the sample. The first significant evidence that emerges from the analysis of reports is that governance, prevention and biodiversity represent the components that companies mainly address in their non-financial disclosure. On the contrary, companies do not provide hardly any information about their implementation of multifunctionality and modularization components.

In almost the totality of the cases, Italian and Japanese companies report information about their contribution to resilience with the almost same ratio. Only in three cases (biodiversity, connectivity and uncertainty) there is an evident difference in companies' disclosure.

Table 1 - Overview of the strategic and instrumental components in reports

\begin{tabular}{|c|c|c|c|c|c|c|}
\hline & \multicolumn{6}{|c|}{ STRATEGIC COMPONENTS } \\
\hline Sample & & Biodiversity & Connectivity & Multifunctionality & Modularization & Adaptive \\
\hline \multirow{2}{*}{ Italy } & Companies & 44 & 25 & 2 & 1 & 9 \\
\hline & $\%$ Italy sample & $47 \%$ & $27 \%$ & $2 \%$ & $1 \%$ & $10 \%$ \\
\hline \multirow{2}{*}{ Japan } & Companies & 41 & 5 & 2 & 0 & 6 \\
\hline & \% Japan sample & $91 \%$ & $11 \%$ & $4 \%$ & $0 \%$ & $13 \%$ \\
\hline \multirow{3}{*}{ Total } & Companies & 85 & 30 & 4 & 1 & 15 \\
\hline & $\%$ total & $62 \%$ & $22 \%$ & $3 \%$ & $2 \%$ & $11 \%$ \\
\hline & \multicolumn{6}{|c|}{ INSTRUMENTAL COMPONENTS } \\
\hline Sample & & Vulnerability & Prevention & Governance & Uncertainty & \\
\hline \multirow{2}{*}{ Italy } & Companies & 18 & 86 & 86 & 29 & \\
\hline & $\%$ Italy sample & $19 \%$ & $92 \%$ & $92 \%$ & $31 \%$ & \\
\hline \multirow{2}{*}{ Japan } & Companies & 10 & 42 & 44 & 19 & \\
\hline & \% Japan sample & $22 \%$ & $93 \%$ & $98 \%$ & $42 \%$ & \\
\hline \multirow[t]{2}{*}{ Total } & Companies & 28 & 128 & 130 & 48 & \\
\hline & $\%$ total & $20 \%$ & $93 \%$ & $94 \%$ & $35 \%$ & \\
\hline
\end{tabular}

* Total of Italian companies=93; total of Japanese companies=45; total companies in the sample: 138 
** Percentages indicate the number of companies that disclose the strategic or instrumental component related, respectively, to the totality of Italian companies, the totality of Japanese companies and the totality of companies included in the sample.

\title{
a) Biodiversity
}

Strategies that support biodiversity are the main strategies that companies address in their reports (62\% of the sample), with the majority belonging to high environmental risk industries such as mining, cement or energy. The spread of the biodiversity issue in company reports is probably due to its explicit inclusion in SDG \#15, which aims to "protect, restore and promote sustainable use of terrestrial ecosystems, sustainably manage forests, combat desertification, and halt and reverse land degradation and halt biodiversity loss," and in six GRI indicators (from EN9 to EN14).

Companies make disclosures about biodiversity in terms of risk and impact limitation, impact measurement and monitoring, and the restoration of pre-existing conditions at the end of activities. Some companies recognize all this biodiversity approaches and embed biodiversity considerations into internal management processes and strategic decision making. For instance, Japan Tobacco underlines how responsible management of biodiversity within operations supports the long-term viability of its business, whilst protecting the environment.

\footnotetext{
"This involves assessing our dependence and impact on biodiversity and natural resources and identifying how we utilize and manage these. We then deploy appropriate responses, such as good agricultural practices, initiatives on soil management, sustainable wood and water conservation, and natural forest restoration. In 2017, we launched our project on nature restoration in Brazil. This was in collaboration with the Society for Wildlife Research and Environmental Education and approved by the National Bank for Social Economic Development. Over the next five years, the project aims to restore 335 ha of Permanent Protection Areas at our integrated tobacco farms as well as in Flona de Irati, a National Forestry Reserve".
}

"Biodiversity", Japan Tobacco 2017 Sustainability report, p. 55

Although the importance of biodiversity is well recognized, companies declare their efforts to foster biodiversity but do not often explain what activities they implement when referring to this aim. However, there are exceptions, with some organizations accurately indicating their practices and publishing ad hoc policies on biodiversity and ecosystem services. Buzzi Unicem's report reads as follows.

\begin{abstract}
"Buzzi Unicem is committed to protecting natural resources impacted by its industrial activities. The main goal of mitigation is to restore previously existing biodiversity by adopting a model grounded on the following principles: optimizing the use of resources and incentivizing the use of secondary raw materials; conducting preliminary assessment of environmental impacts and minimizing them during the life cycle of the extraction activity; preparing a planting plan consistent with the area's rehabilitation project right from the start; legal compliance must be the minimum requirement when establishing each quarry rehabilitation plan; involving stakeholders through transparency, discussion and evaluation of needs of territory and local communities; considering initiatives on biodiversity."

"Environmental performance”, Buzzi Unicem 2016 Sustainability report, p. 60
\end{abstract}

Since the properties of companies often include areas that are commercially productive (for instance mineral sites or cultivated areas) it is important that they take actions to influence how such areas are managed and collaborate with institutions to mitigate their environmental impacts of their activities. The need for collaboration with institutions and research centers emerges in some cases. Costa Cruises affirms as follows: 
"Costa Cruises has always been at the forefront of scientific research efforts, projects
and partnerships aimed at protecting the sea. Our alliances with the CNR11 and, more
particularly, with ISMAR12 are examples of the way in which we contribute to activities
designed to study and monitor the state of health of the marine environment."
"The environment our earth, our home", Costa Cruises 2016 Sustainability report, p. 60

\title{
b) Urban connectivity
}

Since urban connectivity is highly developed for connectivity-dependent functions, industries such as communication and energy distribution play a fundamental role in its implementation and are included in $22 \%$ of companies that consider urban connectivity in their non-financial disclosures. From the reports emerges that urban connectivity mainly refers to physical connectivity (e.g. transportation) and information connectivity.

According to SDG \#11, urban connectivity includes the adoption of sustainable transport, which is useful for achieving a "better integration of the economy while respecting the environment. improving social equity, health, resilience of cities, urban-rural linkages and productivity of rural areas".

For instance, the inclusion of road works in the natural and urban environment generates a set of effects and environmental impacts on the territory, influencing and altering landscapes and various ecosystems. On the other hand, maximizing urban connectivity can provide benefits in terms of the movement of people and species. Companies operating in transportation, communication, and energy distribution industries could emphasize their role in fostering resilience through the spatial connection of urban areas. However, they do not explicitly link their activities to the improvement of resilience; rather, companies limit their reports to explain how connections are implemented with respect to the ecosystem, as the following excerpt from the sustainability report of Ferrovie dello Stato Italiane illustrates:

\begin{abstract}
"Ferrovie dello Stato Italiane takes on the role of gateway to the mobility ecosystem, in an integrated perspective, in a sustainable way, avoiding the construction of unnecessary infrastructures and not involving protected areas; reducing impacts to a minimum, where it is not possible to prevent them, with appropriate measures (underpasses, overpasses, fences), restoring the overall value of biodiversity lost due to the construction of the infrastructure."

"Territory protection", Ferrovie dello Stato Italiane 2016 Sustainability report, p. 176
\end{abstract}

Information connectivity is resilient when can connect people even though difficult circumstance. KDDI explains its contribution to urban connectivity as follows:

\begin{abstract}
"KDDI is aware of the role of communications as a vital lifeline service.
We are implementing various measures to ensure that we can maintain reliable communication services at all times under any circumstances. At times of disasters, we prioritize the maintenance and speedy restoration of communication services and install public wireless LAN and charging facilities at evacuation centers".
\end{abstract}

“Disaster Relief \& Support”, KDDI 2017 Sustainability report

\section{c) Multifunctionality}

Companies disclose their beneficial impacts on territories across production, ecological, and cultural dimensions, without referring to the term "multifunctionality" (we count only 4 companies in the sample that cited this strategy). However, companies underline the multiple roles of their activities in affecting the environment and society. In line with the literature, this aspect has been highlighted by organizations that are active in the agri-food industry. Combining agricultural activities with the maintenance of biodiversity, cultural ecosystem services, recreation, integration, social sustainability and social cohesion, agri-food companies 
contribute to fostering resilience. Fruttagel's report indicates the implementation of multifunctionality, enhancing four main aspects of the impact of its activities: the environment, nutrition, the economy, and culture. Thus, the company lists objectives that refer to each aspect and underlines the critical role of urban institutions in pursuing these objectives.

"Following sustainable agricultural practices; encouraging resilience production systems;
developing and maintain diversity; promoting different varieties of food; producing nutrient
foods; promoting self-sufficiency through local productions; strengthen local food systems
(...)" "Quality, food safety and innovation", Fruttagel 2016 Sustainability report, p. 54

d) Modularization

Modularization implies that system components have enough independence that damage to or the failure of one part or component of a system will, by design, have a low probability of inducing the failure of other similar or related components in the system.

Modular design is also used to solve service provision problems in remote locations and hostile urban environments. Moreover, a consistently implemented modularization makes possible versatile production processes, cost reductions, efficiency gains and considerable versatility. Cities that are served by modular and interconnected systems (e.g., power, water, transportation, health) are consequently less vulnerable to extreme events than are cities that are wholly dependent on one single central system, with few options in the event of a failure. Thus, companies adopt a modular approach to be resilient in the case of damage. Only a few companies (2\%) illustrate this aspect in their report, probably because of the complexity of explaining modularization. No Japanese companies disclosed about modularization.

For example, companies belonging to the energy industry modularize their infrastructure to cover the whole population of the territory and to provide energy in the case of electrical overloads.

\footnotetext{
"In December 2015 the Municipality of Milan and A2A announced an extraordinary fouryear plan to improve the resilience of the electricity grid in the most critical areas of the city, so as to support any exceptional electrical loads, for a total investment of 13 million euros".
}

“Manufacturing capital”, A2A 2016 Integrated report, p. 58

Modularization of system components can regard not only physical infrastructures used in the regular activities of organizations, but also organizational units created for handling emergencies. JXTG, depending on the magnitude of the emergency, establishes an Emergency Headquarters or a Joint Emergency Headquarters with Group companies to ensure swift and appropriate response to the crisis in order to fulfill the social mission of the Group. In this case, modularization of emergency managerial structures enables the company to address catastrophic events that can happens in dislocated areas. However, emergency systems include also modularization of physical components, as emerges from the report of JXTG:

\footnotetext{
"We regularly implement comprehensive disaster drills for our own disaster response organizations to ensure that we can respond in a quick and agile manner should an actual disaster occur. We also hold other drills, including joint disaster preparedness drills involving local fire departments and disaster response organizations from nearby companies “"

"Measures to Cope with Accidents and Problems", JXTG 2017 CSR report, p. 51
} 
Adaptive design is the basis for the operationalization of urban resilience, highlighting the need to actively solve problems collaboratively by exercising imagination and creativity and presenting new and potentially fertile sources of innovation. In this vein, social resilience thinking creates opportunities for innovation and development, going beyond the capacity to absorb shock and retain core functions to embrace the potential for renewal and development. In communicating their adaptive design practices, companies refer to SDG \#13, which calls for companies to make efforts to redress climate change through both adaptation and mitigation that are able to similarly inform and shape the global development agenda.

The 15 companies in the sample that make disclosures about the implementation of adaptive design adopt two different acceptations. First, they refer to adaptive design management and policy development in collaboration with institutions. TIM, for instance, provides a summary of the initiatives implemented in partnership with several stakeholders, indicating the established object, the actions carried out, and the partner is collaborating with. An initiative that considers resiliency and concerns the design of its structures is described as follows:

\footnotetext{
"In order to prevent or limit the potential damage, TIM's new exchanges and buildings are built at a safe distance from rivers and bodies of water in general and, in order to ensure continuity of service, the network is designed considering appropriate levels of resilience and redundancy".

"Climate change", TIM 2017 Sustainability report, p. 52
}

Second, they refer to the design of their structures and products to guarantee resilience and safety. For example, Mazda innovatively designs its production to protect human safety on the road and to prevent connectivity congestion.

\begin{abstract}
"Traffic accidents and congestion are serious social problems in many countries and cities. To solve these problems, worldwide efforts have been taken to introduce advanced technologies for roads and automobiles. As an automobile manufacturer, Mazda has been proactively supporting the ITS project and working collaboratively with the government, local communities, and related companies in order to realize a society where the road traffic is safe and accident-free"
\end{abstract}

“Safety”, Mazda 2017 Sustainability report, p. 52

\title{
f) Vulnerability
}

According to the literature, companies try to reduce the vulnerability of urban territories by implementing a risk management program that limits and avoids partial risk and shares unavoidable risks with other parties. In general, the 28 companies that include vulnerability in their reports refer to three typologies of risk in their reports. They recognize information resilience vulnerability and protect their information assets from risks such as cyberattacks, leakages or disasters, adopting information management systems. Other companies address social resilience vulnerability by addressing human rights risks in the supply chain, such as modern slavery and conflict minerals. Some companies focus on environmental vulnerability, reducing water usage by promoting various water conservation and water leakage prevention measures as well as reducing $\mathrm{CO} 2$ emissions by changing the heat source for producing water to a source of surplus electric power at power plants. In this regard, companies refer to SDG \#1, which highlights the need to "build the resilience of the poor and those in vulnerable situations and reduce their exposure and vulnerability to climate-related extreme events and other economic, social and environmental shocks and disasters." The reduction of these risks implies the creation of proper efficient infrastructures that protect urban vulnerabilities.

"The Group adopts procedures, behaviours, technology and in-vestments to guarantee the latest and best possible standards. The celebration of 10 years of operation of the constitution of the Consulta per la Sicurezza e la Qualità del Servizio (Council Constitution 
for Safety and Service Quality), an initiative promoted in 2005 to foster collaboration between Autostrade per l'Italia, consumer associations, institutions and economic operators (Codacons, Adusbef, Federconsumatori and Adoc, the Police, Adiconsum, Asaps, Isoradio".

“Social capital”, Atlantia 2016 Integrated report, p. 76

Other companies analyze the risks for each aspect included in GRI guidelines and the impact they would have on the company and the territory. Casio discloses a table in its CSR report where the company discusses the management of risks associated to different aspects of its activity (corruption, information security, supply chain, social and environmental issues among others). Casio clearly describes the tasks of the CSR office manager that addresses social resilience vulnerability.

"He [the CSR office manager] explained the potential for serious business and credit risk arising from any improper protection of worker rights and presented specific examples of human rights issues to be looked at in the supply chain. The aim was to promote through understanding of the importance of taking steps to protect human rights".

"Responsibilities to suppliers", Casio 2017 Sustainability report, p. 97

\section{g) Prevention}

The prevention approach is expressed by the majority of reports (93\% of the sample), which highlight that the prediction and prevention of a risk (ex-ante intervention) are better than its remediation (ex post intervention). Contributing to urban resilience through prevention implies two main activities of companies within a territory: informative prevention and structural prevention. The latter enables companies to internally implement their systems in preparation for future possible disasters. Ordinary infrastructure monitoring also enables companies to identify losses or malfunctions more quickly, significantly improving their performance. For example, Nissan declares to help address a range of issues toward the realization of a society with less urban traffic congestion and more ways for older citizens to move about safely.

"Nissan is enhancing its preventive safety technologies to support the four basic steps in avoiding accidents: sensing, cognition, judgment and action [...] In a society facing issues including aging populations and urban congestion, autonomous driving technologies may one day be able to help reduce traffic accidents, thus providing peace of mind to drivers and increasing mobility for the rapidly growing number of senior citizens".

"Safety", Nissan 2017 Sustainability report, p. 51

Informative prevention consists of informing and educating the population about eventual risks and is mainly directed toward consumers and employees. Some companies decide to safeguard the territory through awareness campaigns for a responsible use of their products. Others work on fundamental issues such as the circular economy, urban regeneration, land security, seismic prevention and intelligent city development. An example is provided below by Enel:

\footnotetext{
"Enel and ANCI (National Association of Italian Municipalities) signed a protocol to increase the awareness of Italian institutions and operators about the themes and investments to make Italian cities more resilient, putting its experience and skills at the service of the country. In particular, Enel and ANCI undertook to stimulate the adhesion of Italian cities to the campaign of the United Nations "Making Cities Resilient", acknowledging that mayors have a key role for the development of the local area and as a driver for the implementation of operational plans. During 2016, with the collaboration of the regional European office of the United Nations Office for Disaster Risk Reduction (UNISDR) a training module was drawn up on resilience, with a specific focus on strategic and operational impacts. The program, which is included in the MBA courses and PhDs of leading Italian universities, saw the participation of over 120 people."
}

"Our commitment", Enel 2016 Sustainability report, p. 110 


\section{h) Governance}

Formulating policy and appropriate governance structures can enable, accommodate and facilitate companies in positively affecting urban resilience. The structure and mission of corporate governance are widely addressed by companies in their responsibility reports (94\% of the sample). Indeed, governance plays a critical role in creating strategies and plans that aim to achieve the SDGs.

On the one hand, the openness of companies' governance to the dialogue with several internal and/or external stakeholders - in a few cases also with their inclusion in decision-making - is a useful instrument to improve urban resilience. For instance, gradual consultation with senior management and the main areas of companies stimulates constructive dialogue concerning the strategic direction of future sustainability efforts and the definition of sustainability policies in line with the SDGs.

Companies recognize that the development of policies in line with the SDGs allows them to understand the contribution of their activities and to acknowledge how the private sector can have a central role as an agent of change in facing major global challenges. In particular, good governance and dialogue with different stakeholders is helpful in achieving SDGs \#5, \#9, \#11 and \#16.

\footnotetext{
"Governance (ESG) criteria has been adopted as a major indicator of corporate value. In particular, the number of opportunities has risen to respond to requests from our customers to confirm how we are responding to the needs of people and society at large within our activities in the B-to-B sphere and transactions with governmental and municipal entities, which we are working to strengthen."

"Message from management", Canon 2017 Sustainability report, p. 4
}

The inclusion of resilience and sustainability in the main mission of companies enhances their effort to achieve SDGs and their priority to the realization of such goals. For instance, Banca Intesa highlights its strong commitment to build resilient infrastructures, to promote inclusive and sustainable industrialization, and to foster innovation as well as make cities and human settlements inclusive, safe, resilient and sustainable.

"The growth strategy of the Bank strives to create stable and sustainable values from
the economic, financial, social and environmental aspect, building on the fundamental
corporate values of the Bank in relations with all stakeholders".
"Bank profile", Banca Intesa 2017 Sustainability report, p. 10

\section{i) Uncertainty orientation}

To adopt an uncertainty approach, on the one hand, companies try to define the conditions under which a disaster would occur and what factors can affect current conditions. On the other hand, companies engineer systems to avoid or survive disasters. We identify three main uncertainty issues with which $35 \%$ of companies declare that they must cope. First, uncertainty is associated with the policy environment. This uncertainty refers to regulatory instability that belongs to the external environment (policy of institutions) or the internal environment (corporate policy). Policy uncertainty due to the external environment is difficult to control - although it is a little easier to predict. Internal policy uncertainty can be addressed by companies through effective policy designs. Second, uncertainty is linked to the natural environment, which can provoke unexpected contingencies that affect the resilience of cities and their citizens. In this case, climate change can directly affect physical structures but also the resilience of business, as emerged from the Sustainability report of ENI and other companies within the insurance and bank industries. A number of international organizations (particularly UNEP, the European Union and the OECD), have recognized and often emphasized the important role that the world 
of insurance and bank can play in the fight against climate change, especially in terms of the prevention and management of associated risks, by creating and conceptualizing new products and services, as well as making long-term investments intended to increase the resilience of residents, businesses and communities. Companies express their awareness of the unpredetermined scenarios that climate change or earthquakes can cause, limiting the effectiveness of current policy responses. However, they try to reduce uncertainty as much as possible through "resilient" strategies.

\begin{abstract}
"Climate change risk identifies the possibility of changes occurring to aspects associated with climate change which may generate, in the short, medium and long term, physical and other risks which impact on the business. The risks and opportunities associated with climate change, analysed particularly with regard to the four-year strategic plan and over the long term, concern: Extreme/ chronic weather and climate phenomena with a possible increase in costs (including insurance) for adaptation measures to protect assets and people, Uncertainty over the evolution of the energy mix and hydrocarbon prices in a low-carbon context, with effects on the demand for fossil fuels, on project operating costs and profitability or Speed of development of lowcarbon technological solutions and consequent uncertainty regarding the effects on business".

“Path to decarbonization”, Eni Spa 2016 Sustainability report, p. 13-14
\end{abstract}

Third, uncertainty can include the infrastructures of companies and their efficiency in contributing to urban resilience. In this regard, the involvement of concerned parties in the planning processes and in the development of infrastructure is an essential element to monitor and control uncertain events and consequences.

Table 2 summarizes, on the one hand, the strategic components and instruments that the academic literature suggests to institutions and organizations for the implementation of urban resilience, and, on the other hand, the role that companies can play, as it emerges from the content analysis of their non-financial disclosure. Thus, the table shows a synoptic overview of the strategic and instrumental components of resilience planning, providing a definition for each element, describing their impact on cities, and suggesting the contribution of companies to urban resilience achievement.

Table 2 - Overview of the strategic and instrumental components of resilience planning

\begin{tabular}{|l|l|l|l|l|}
\hline & Component & Definition & Impact & Companies' contributions \\
\hline \multirow{5}{*}{ Biodiversity } & $\begin{array}{l}\text { "A diversity of species and } \\
\text { ecosystems that collectively } \\
\text { support specific functions } \\
\text { but respond differently to } \\
\text { change and disturbance" } \\
\text { (Ahern, 2013, p. 1206) }\end{array}$ & $\begin{array}{l}\text { It concerns the impact of the } \\
\text { city and the region itself on } \\
\text { adjacent ecosystems, the } \\
\text { maximization of biodiversity } \\
\text { within the urban ecosystem, } \\
\text { the management of } \\
\text { undesirable species within } \\
\text { the ecosystem. }\end{array}$ & $\begin{array}{l}\text { Companies contribute to } \\
\text { biodiversity: } \\
\text { - Monitoring and measuring } \\
\text { possible and actual impact } \\
\text { (of the company's activities) } \\
\text { - Limitation of possible risks } \\
\text { and actual impact } \\
\text { - Restoration of pre- } \\
\text { conditions }\end{array}$ \\
\cline { 2 - 6 } & \multirow{2}{*}{$\begin{array}{l}\text { Urban } \\
\text { connectivity }\end{array}$} & $\begin{array}{l}\text { "The ability to create and } \\
\text { maintain a connection } \\
\text { between two or more points } \\
\text { in a spatial system" } \\
\text { (Reggiani, Nijkamp and } \\
\text { Lanzi, 2015, p. 5) }\end{array}$ & $\begin{array}{l}\text { It concerns establishing or } \\
\text { restores the linkages } \\
\text { between areas through } \\
\text { ecological corridors, which } \\
\text { is necessary to facilitate their } \\
\text { ecological functions. }\end{array}$ & $\begin{array}{l}\text { Companies can improve } \\
\text { urban connectivity creating } \\
\text { and maintaining: } \\
\text { - Connectivity of physical } \\
\text { structures } \\
\text { - Information connectivity }\end{array}$ \\
\cline { 2 - 5 } & Multifunctionality & $\begin{array}{l}\text { "Deliberate provision of } \\
\text { multiple ecosystem }\end{array}$ & $\begin{array}{l}\text { It concerns obtaining a more } \\
\text { efficient use of space in }\end{array}$ & $\begin{array}{l}\text { Companies can foster the } \\
\text { multiple roles of their }\end{array}$ \\
\hline
\end{tabular}









\section{Conclusions}

This study contributes both to the literature on social and environmental accounting and to the literature on sustainability and urban resilience by highlighting, firstly, how companies disclose on their impacts on urban resilience using the SDGs and the GRI guidelines and, secondly, how companies can foster urban resilience through the strategies and actions they implement and report.

Considering that the concept of resilience is acknowledged in many targets of the SDGs, this research aims to fill the existing gap between theoretical considerations and practice about the role of companies in fostering urban resilience. More specifically, we provided insights into the contribution of companies to the resilience of cities and regions, advancing the literature on the link between business and resilience and the SDGs and offering a new frame that can help companies foster the resilience of territories. Greater attention to disclosures on the impacts of companies on resilience is a starting point for action towards achieving the SDGs.

Our contribution proposes a unitary framework based on the original union of the Ahern's strategies (2003) and Jabareen's instrumental components (2013), combined with an analysis of how companies contribute to city and community urban resilience. We have tried to understand how companies operationalize resilience as an SDG through their sustainability reports by understanding what types of resilience components and strategies they cope with.

The first important evidence emerging from our analysis is that the biodiversity strategy, on one hand, and the prevention and governance instrumental components, on the other hand, represent the main attention points addressed by companies in their reports. This greater presence is certainly motivated by the adoption of the GRI guidelines by the companies analyzed since the guidelines require specific mandatory indicators for biodiversity, governance, and prevention. Furthermore, these topics probably lend themselves more than others to greater information dissemination concerning the sustainability of companies to potential stakeholders since they do not always hold specialist knowledge on resilience issues, which can sometimes require technical and professional characteristics.

In contrast, multifunctionality and modularization represent the resilience components characterized by a greater degree of technicality, and they are not only more difficult to communicate to stakeholders but also extremely diversified among the operative sectors of the sample companies. Furthermore, both multifunctionality and modularization depend on the size of the organization and on the concrete impact that companies can have on the urban system. In other words, not all sample companies could have real needs to provide multiple ecosystem services or to split into different modules or subsystems.

The remaining components (adaptive design, vulnerability, urban connectivity, and uncertain orientation) have a presence in the analyzed reports ranging from a minimum of $10 \%$ (adaptive design) to a maximum of $35 \%$ (uncertain orientation) and are characterized by a lower degree of technical complexity with respect to multifunctionality and modularization and partly lend themselves to more effective communication with stakeholders. However, between the indicators and compulsory information required by the GRI guidelines, they are not always explicitly predicted. Moreover, they are among the resilience components with a more diversified degree of disclosure and degree of articulation, with very different levels of information quality provided.

A first possible conclusion, even if implicit in our research design, is that the resilience components of cities are destined to obtain a greater space and articulation in reports that follow guidelines that explicitly predict these aspects among the compulsory information for reporters. A second conclusion is related to the degree of technical complexity of the analyzed resilience components. The higher this level is, the greater the likelihood that the information in sustainability reports is limited or even absent, given that the sustainability reports are intended for a wide range of stakeholders, who often do not have technical or professional knowledge 
on specific aspects of companies' performance. This conclusion opens the door to further research, that should provide new approaches useful to address urban resilience in a comprehensible way for stakeholders and improve urban resilience reporting efficacy. Possible implication for theory and practice are how to simplify or modularize information provided by companies in their sustainability reports on the most technically complex aspects of the cities' resilience, so that even small companies, with little experience on these issues, can still report on their impacts. In this vein, dialogic accounting - interpreted as an innovative practice that has the potential to stimulate interaction and dialogue with and among different stakeholders' groups (Bellucci \& Manetti, 2017) - could be considered by organizations for debating resilience components characterized by a greater degree of technicality. Dialogic accounting can be useful also in the expansion of relationships forged between governments and businesses. Since resilience requires cross-sector collaboration, a "multi-voiced" inclusive instrument that takes into account different stakeholder's values and interests should be investigated in future researches in order to improve urban resilience achievement.

Among the practical implications of the present research, we mention the utility that studying sustainability reports can have for municipalities, public administrations, cross-sector partnerships and the local community at large to understand the degree of the resilience component pursuit. Furthermore, the gaps highlighted in the disclosures related to the majority of resilience components can be an indicator for sustainability reporting guideline standard setters to modify or add indicators or information specifically dedicated to the various aspects of resilience.

Finally, among the limitations of the present research, we recall the content analysis carried out on a large but very heterogeneous sample (in terms of size, sector, etc.) of companies coming from only two countries, albeit united by a high hydrogeological risk. Our analysis suggested that the behavior of Italian and Japanese companies in terms of resilience reporting is similar, with the notable exception of evident discrepancies on the disclosures related to biodiversity, uncertainty, and connectivity (being biodiversity and uncertainty disclosure more frequent in Japanese organizations and connectivity disclosure more frequent in Italian organizations). These differences could be linked to national institutional and legislative characteristics and would deserve further research. Therefore, future studies could expand the field of analysis, including other countries and enriching the framework with additional practices that companies can implement in order to foster the resilience of cities. Moreover, this study analyzes urban resilience from the perspective of companies. Further research could also consider the perspective of municipalities and local institutions, understanding their point of view regarding the possible role of companies towards urban resilience and the opportunities that collaborations between governments and businesses can provide. 


\section{References}

100 Resilient Cities. Principles. (2018). http://www.100resilientcities.org Accessed 2 May 2019.

Abbott, J. (2009). Planning for complex metropolitan regions: a better future or a more certain one?. Journal of Planning Education and Research, 28(4), 503-517.

ANCE/CRESME (2012). Primo Rapporto ANCE/CRESME. Lo Stato Del Territorio Italiano 2012 Insediamento e rischio sismico e idrogeologico. Roma: ANCE/CRESME.

Acuti, D., \& Bellucci, M. (2019), Resilient Cities and Regions: Planning, Initiatives, and Perspectives. In: W. Leal Filho, U. Azeiteiro, A.M. Azul, L. Brandli, P.G. Özuyar, T. Wall. Climate Action, pp. 1-12. Springer. ISBN:9783319958842.

Ahern, J. (2013). Urban landscape sustainability and resilience: the promise and challenges of integrating ecology with urban planning and design. Landscape Ecology, 28(6), 1203-1212.

Bebbington, J., \& Unerman, J. (2018). Achieving the United Nations Sustainable Development Goals: An enabling role for accounting research. Accounting, Auditing and Accountability Journal, 31(1), 2-24, https://doi.org/10.1108/AAAJ-05-2017-2929.

Bahadur, A., Lovell, E., Wilkinson, E., \& Tanner, T. (2015). Resilience in the SDGs: Developing an indicator for Target 1.5 that is fit for purpose. Retrieved from the Overseas Development Institute website: https://www.odi.org/sites/odi.org.uk/files/odiassets/publications-opinion-files/9780.pdf

Bellucci, M., \& Manetti, G. (2017). Facebook as a tool for supporting dialogic accounting? Evidence from large philanthropic foundations in the United States. Accounting, Auditing \& Accountability Journal, 30(4), 874-905.

Bellucci, M., \& Manetti G. (2018). Stakeholder engagement and sustainability reporting. Londra: Routledge. ISBN:978-0-8153-7315-5.

Bellucci, M., Simoni, L., Acuti, D., \& Manetti, G. (2019). Stakeholder engagement and dialogic accounting: empirical evidence in sustainability reporting. Accounting, Auditing \& Accountability Journal, vol. 32(5). ISSN: 1368-0668. doi: 10.1108/AAAJ-09-2017-3158

Berelson, B. (1952). Content analysis in communication research. New York: Free Press.

Berkes, F. (2007). Understanding uncertainty and reducing vulnerability: lessons from resilience thinking. Natural hazards, 41(2), 283-295.

Biggeri, M., Ballet, J., \& Comim, F. (2011). Children and the capability approach. Basingstoke: Palgrave Macmillan.

Biggeri, M., Testi, E.; \& Bellucci, M. (2017). Enabling ecosystems for social enterprises and social innovation: a capability approach perspective. Journal Of Human Development And Capabilities, 18, 299-306, ISSN:1945-2829.

Boyd, E., \& Juhola, S. (2015). Adaptive climate change governance for urban resilience. Urban Studies, 52(7), 1234-1264.

Booher, D. E., \& Innes, J. E. (2010). Governance for resilience: CALFED as a complex adaptive network for resource management. Ecology and Society, 15(3).

Brown, K. (2014). Global environmental change I: A social turn for resilience? Progress in Human Geography, 38(1), 107-117.

Bryman, A. \& Bell, E. (2015), Business research methods, Oxford University Press, USA. 
Bulkeley, H. (2010). Cities and the governing of climate change. Annual Review of Environment and Resources, 35.

Caiado, R. G. G., Leal Filho, W., Quelhas, O. L. G., de Mattos Nascimento, D. L., \& Ávila, L. V. (2018). A literature-based review on potentials and constraints in the implementation of the sustainable development goals. Journal of Cleaner Production, 198, 1276-1288.

Campbell-Arvai, V. (2018). Engaging urban nature: improving our understanding of public perceptions of the role of biodiversity in cities. Urban Ecosystems, 22(2), 409-423.

Carpenter, S., Walker, B., Anderies, J. M., \& Abel, N. (2001). From metaphor to measurement: Resilience of what to what?. Ecosystems, 4, 765-781.

Chen, C. W., Tseng, C. P., Hsu, W. K., \& Chiang, W. L. (2012). A novel strategy to determine the insurance and risk control plan for natural disaster risk management. Natural Hazards, 64(2), 1391-1403.

Ciani, F., Huggard, J., \& Zervas, T. (2016). The Resilience of Bergamot Farmers to Economic Shocks in the Reggio Calabria Province. Regions Magazine, 302(1), 23-25.

Coaffee, J. (2013). Rescaling and responsibilising the politics of urban resilience: From national security to local place-making. Politics, 33(4), 240-252.

Crane, A. (1998). Exploring green alliances. Journal of Marketing Management, 14(6), 559579 .

Crane, A., \& Matten, D. (2016). Engagement required: the changing role of the corporation in society. In D. Barton, D. Horvath, and M. Kipping (Eds.), Re- imagining capitalism: building a responsible, long-term model. Oxford: Oxford University Press.

De Montis, A., Caschili, S., Mulas, M., Modica, G., Ganciu, A., Bardi, A., ... \& Fichera, C. R. (2016). Urban-rural ecological networks for landscape planning. Land Use Policy, 50, 312327.

De Jong, M., Joss, S., Schraven, D., Zhan, C., \& Weijnen, M. (2015). Sustainable-smartresilient-low carbon-eco-knowledge cities; Making sense of a multitude of concepts promoting sustainable urbanization. Journal of Cleaner Production, 109, 25-38.

Delmas, M., \& Marcus, A. (2004). Firms' choice of regulatory instruments to reduce pollution: A transaction cost approach. Business and Politics, 6(3), 1-20.

Desouza, K.C., \& Flanery, T.H. (2013). Designing, planning, and managing resilient cities: A conceptual framework. Cities, 35, 89-99.

Diouf, D., \& Boiral, O. (2017). The quality of sustainability reports and impression management: A stakeholder perspective. Accounting, Auditing \& Accountability Journal, 30(3), 643-667.

Elo, S., \& Kyngäs, H. (2008). The qualitative content analysis process. Journal of Advanced Nursing, 62(1), 107-115.

Gellers, J. C. (2016). Crowdsourcing global governance: sustainable development goals, civil society, and the pursuit of democratic legitimacy. International Environmental Agreements: Politics, Law and Economics, 16(3), 415-432.

Global Reporting Initiative (2016). Consolidated Set of Standards. Amsterdam: GRI.

Godschalk, D.R. (2003). Urban hazard mitigation: Creating resilient cities. Natural Hazards Review, 4(3), 136-143. 
Goldstein, B. E., Wessells, A. T., Lejano, R., \& Butler, W. (2015). Narrating resilience: Transforming urban systems through collaborative storytelling. Urban Studies, 52(7), 12851303.

Griffin, P. (2017). The Carbon Majors Database. CDP Carbon Majors Report 2017. CDP, London.

Guthrie, J., Petty, R., Yongvanich, K. \& Ricceri, F. (2004). Using content analysis as a research method to inquire into intellectual capital reporting. Journal of Intellectual Capital, 5(2), 282293.

Hediger, W. (2008). Agriculture's multifunctionality, sustainability, and social responsibility. In 82nd Annual Conference Sustainability, and Social Responsibility", Agricultural Economics Society (AES). Royal Agricultural College, UK.

Holling, C. S. (1996). Engineering resilience versus ecological resilience. Engineering within ecological constraints, 31(1996), 32.

Hsieh, H.-F., \& Shannon, S. E. (2005). Three approaches to qualitative content analysis. Qualitative Health Research, 15(9), 1277-1288.

Hudson, R. (2010). Resilient regions in an uncertain world: Wishful thinking or a practical reality?. Cambridge Journal of Regions, Economy and Society, 3(1), pp. 11-25.

Hudec, O., Reggiani, A., \& Šiserová, M. (2018). Resilience capacity and vulnerability: A joint analysis with reference to Slovak urban districts. Cities, 73, 24-35.

Hutter, G. (2016). Collaborative governance and rare floods in urban regions-Dealing with uncertainty and surprise. Environmental science and policy, 55, 302-308.

ISPRA (2015). Hydrogeological instability in Italy: hazard and risk indicators - Report 2015. Roma: ISPRA Istituto Superiore per la Protezione e la Ricerca Ambientale. ISBN: 97888-448-0751-1.

Jabareen, Y. (2013). Planning the resilient city: Concepts and strategies for coping with climate change and environmental risk. Cities, 31, 220-229.

Jones, P.' \& Comfort, D. (2018). Sustainable Consumption and the Leading US Retailers. Indonesian Journal of CSR and Environmental Management, 1(1).

Kyngas, H., \& Vanhanen, L. (1999). Content analysis. Hoitotiede, 11(3-12).

Klein, R. J., Nicholls, R. J., \& Thomalla, F. (2003). Resilience to natural hazards: How useful is this concept?. Global Environmental Change Part B: Environmental Hazards, 5(1-2), 35-45.

Koch, F., \& Ahmad, S. (2018). How to Measure Progress Towards an Inclusive, Safe, Resilient and Sustainable City? Reflections on Applying the Indicators of Sustainable Development Goal 11 in Germany and India. In Urban Transformations (pp. 77-90). Springer, Cham.

Krippendorff, K. (2004). Content analysis: An introduction to its methodology. London: Sage. Lee, Y. J. (2014). Social vulnerability indicators as a sustainable planning tool. Environmental Impact Assessment Review, 44, 31-42.

Leichenko, R. (2011). Climate change and urban resilience. Current opinion in environmental sustainability, 3(3), 164-168.

Leitner, H., Sheppard, E., Webber, S., \& Colven, E. (2018). Globalizing urban resilience. Urban Geography, 1-9. 
Le Ber, M. J., \& Branzei, O. (2010). (Re) forming strategic cross-sector partnerships: Relational processes of social innovation. Business and Society, 49(1), 140-172.

Linnenluecke, M., \& Griffiths, A. (2010). Beyond adaptation: resilience for business in light of climate change and weather extremes. Business and Society, 49(3), 477-511.

andLovell, S. T., \& Taylor, J. R. (2013). Supplying urban ecosystem services through multifunctional green infrastructure in the United States. Landscape ecology, 28(8), 14471463.

Luederitz, C., Lang, D. J., \& Von Wehrden, H. (2013). A systematic review of guiding principles for sustainable urban neighborhood development. Landscape and Urban Planning, 118, 40-52.

Manetti, G., \& Bellucci, M. (2016). The use of social media for engaging stakeholders in sustainability reporting. Accounting, Auditing \& Accountability Journal, 29(6), 985-1011. doi:10.1108/AAAJ-08-2014-1797.

Meerow, S., Newell, J. P., \& Stults, M. (2016). Defining urban resilience: A review. Landscape and urban planning, 147, 38-49.

Milliman, J., \& Grosskopf, J. (2004). Improving the regulatory enforcement settlement process: Applying collaborative solutions for businesses and environmental regulatory agencies. Environmental Quality Management, 13(3), 25-43.

Milne, M. J., \& Adler, R. W. (1999). Exploring the reliability of social and environmental disclosures content analysis. Accounting, Auditing \& Accountability Journal, 12(2), 237-256.

Munich RE (2017a). Natural catastrophes 2016: Analyses, assessments, positions, Topics Geo, 2017 Issue, Munich, Germany.

Normandin, J. M., \& Therrien, M. C. (2016). Resilience factors reconciled with complexity: The dynamics of order and disorder. Journal of Contingencies and Crisis Management, 24(2), 107-118.

Olazabal, M., Chelleri, L., \& Sharifi, A. (2018). Is Connectivity a Desirable Property in Urban Resilience Assessments?. In Resilience-Oriented Urban Planning (pp. 195-211). Springer, Cham.

Oliva, S. \& Lazzeretti, L. (2017). Adaptation, adaptability and resilience: the recovery of Kobe after the Great Hanshin Earthquake of 1995, European Planning Studies, 25(1), 67-87. DOI: 10.1080/09654313.2016.1260093

Oliva, S., \& Lazzeretti, L. (2018). Measuring the economic resilience of natural disasters: An analysis of major earthquakes in Japan. City, culture and society, 15, 53-59.

Pahl-Wostl, C. (2006). The importance of social learning in restoring the multifunctionality of rivers and floodplains. Ecology and society, 11(1).

Pinkse, J., \& Kolk, A. (2012). Addressing the climate change - sustainable development nexus: The role of multistakeholder partnerships. Business and Society, 51(1), 176-210.

Pizzo, B. (2015). Problematizing resilience: Implications for planning theory and practice. Cities, 43, 133-140.

Rainey, H. J., Pollard, E. H., Dutson, G., Ekstrom, J. M., Livingstone, S. R., Temple, H. J., \& Pilgrim, J. D. (2015). A review of corporate goals of No Net Loss and Net Positive Impact on biodiversity. Oryx, 49(2), 232-238. 
Rimmel, G., \& Jonäll, K. (2013). Biodiversity reporting in Sweden: corporate disclosure and preparers' views. Accounting, Auditing and Accountability Journal, 26(5), 746-778.

Roos, P. B. (2014). Regenerative-adaptive design: Patterns to coastal resilience. In Practical Responses to Climate Change Conference 2014 (p. 37). Engineers Australia.

Sachs, J. D. (2012). From millennium development goals to sustainable development goals. The Lancet, 379(9832), 2206-2211.

Saldaña-Zorrilla, S. O. (2008). Stakeholders' views in reducing rural vulnerability to natural disasters in Southern Mexico: Hazard exposure and coping and adaptive capacity. Global Environmental Change, 18(4), 583-597.

SDGS (2019). "Vulnerability-Resilience Country Profile". https://sustainabledevelopment.un.org/content/documents/1982Vulnerability-

Resilience\%20Country\%20Profile\%20(VRCP).pdf.

Selsky, J. W., \& Parker, B. (2005). Cross-sector partnerships to address social issues: Challenges to theory and practice. Journal of management, 31(6), 849-873.

Swiss RE (2017) Natural catastrophes and man-made disasters in 2016: A year of widespread damages, sigma, 2.

Sharifi, A., \& Yamagata, Y. (2016). Principles and criteria for assessing urban energy resilience: A literature review. Renewable and Sustainable Energy Reviews, 60, 1654-1677.

Testi, E., Bellucci, M., Franchi, S., \& Biggeri, M. (2017). Italian Social Enterprises at the Crossroads: Their Role in the Evolution of the Welfare State. VOLUNTAS: International Journal of Voluntary and Nonprofit Organizations, 28(6), 2403-2422.

The Global Goals (2019). https://www.globalgoals.org/17-partnerships-for-the-goals.

Thorne, L., S. Mahoney, L., \& Manetti, G. (2014). Motivations for issuing standalone CSR reports: A survey of Canadian firms. Accounting, Auditing \& Accountability Journal, 27(4), 686-714.

UN (2015). Transforming our world: The 2030 agenda for sustainable development. https://sustainabledevelopment.un.org/post2015/transformingourworld/publication Accessed 02 July 2019.

Von Malmborg, F. (2003). Conditions for regional public-private partnerships for sustainable development - Swedish perspectives. European Environment, 13(3), 133-149.

Wassmer, U., Paquin, R., \& Sharma, S. (2014). The engagement of firms in environmental collaborations: Existing contributions and future directions. Business and Society, 53(6), 754786.

Watson, B. (2014). What makes a city resilient?, The Guardian, Retrieved on https://www.theguardian.com/cities/2014/jan/27/what-makes-a-city-resilient

Webb, E.J., Campbell, D.T., Schwartz, R.D. \& Sechrest, I. (1966), Unobtrusive Measures: Non-reactive Research in the Social Sciences, Rand McNally, Chicago, IL.

Wood, D. J. (1991). Corporate social performance revisited. Academy of management review, 16(4), 691-718.

Zhang, X., \& Li, H. (2018). Urban resilience and urban sustainability: What we know and what do not know?.Cities, 72, 141-148. 



\section{Appendix}

Table A - Main characteristics of the 138 included organizations and their sustainability reports

\begin{tabular}{|c|c|c|c|c|c|c|c|}
\hline Name & Country & Size & $\begin{array}{l}\text { Organization } \\
\text { type }\end{array}$ & \begin{tabular}{|l|} 
Listed// \\
Non-listed
\end{tabular} & Sector & $\begin{array}{l}\text { External } \\
\text { Assurance }\end{array}$ & $\begin{array}{l}\text { SDGs } \\
\text { Link }\end{array}$ \\
\hline A2A spa & Italy & Large & Private company & Listed & $\begin{array}{l}\text { Energy } \\
\text { Utilities }\end{array}$ & Yes & Yes \\
\hline A.C. Milan (charity) & Italy & Large & $\begin{array}{l}\text { Non-profit } \\
\text { organization }\end{array}$ & Non-listed & $\begin{array}{l}\text { Non-Profit / } \\
\text { Services }\end{array}$ & No & No \\
\hline AC Milan & Italy & SME & Private company & Non-listed & Other & No & No \\
\hline Anas S.p.A. & Italy & Large & $\begin{array}{l}\text { State-owned } \\
\text { company }\end{array}$ & Listed & Other & Yes & No \\
\hline Ansaldo STS & Italy & Large & Private company & Listed & Logistics & Yes & No \\
\hline Aquafil & Italy & Large & Private company & Non-listed & $\begin{array}{l}\text { Textiles and } \\
\text { Apparel }\end{array}$ & No & No \\
\hline Aspiag Service Srl & Italy & MNE & Private company & Non-listed & Retailers & Yes & No \\
\hline Atlantia & Italy & Large & Private company & Listed & Construction & Yes & No \\
\hline Banca Generali & Italy & Large & Private company & Listed & $\begin{array}{l}\text { Financial } \\
\text { Services }\end{array}$ & No & No \\
\hline BPER Banca & Italy & Large & Private company & Listed & $\begin{array}{l}\text { Financial } \\
\text { Services }\end{array}$ & Yes & No \\
\hline Buzzi Unicem & Italy & Large & Private company & Listed & $\begin{array}{l}\text { Construction } \\
\text { Materials }\end{array}$ & Yes & No \\
\hline Carlsberg Italia & Italy & Large & Subsidiary & Non-listed & $\begin{array}{l}\text { Food and } \\
\text { Beverage } \\
\text { Products }\end{array}$ & No & Yes \\
\hline Cementir Holding & Italy & MNE & Private company & Listed & $\begin{array}{l}\text { Construction } \\
\text { Materials }\end{array}$ & No & No \\
\hline CIR Group & Italy & MNE & Private company & Listed & $\begin{array}{l}\text { Conglomerate } \\
\mathrm{s}\end{array}$ & Yes & No \\
\hline Colacem & Italy & Large & Private company & Non-listed & $\begin{array}{l}\text { Construction } \\
\text { Materials }\end{array}$ & Yes & No \\
\hline Comieco & Italy & SME & $\begin{array}{l}\text { Non-profit } \\
\text { organization }\end{array}$ & Non-listed & $\begin{array}{l}\text { Waste } \\
\text { Management }\end{array}$ & No & No \\
\hline CONAI & Italy & Large & Public institution & $\begin{array}{l}\text { Not } \\
\text { applicable }\end{array}$ & $\begin{array}{l}\text { Waste } \\
\text { Management }\end{array}$ & No & No \\
\hline CONI & Italy & Large & $\begin{array}{l}\text { State-owned } \\
\text { company }\end{array}$ & Non-listed & $\begin{array}{l}\text { Public } \\
\text { Agency }\end{array}$ & Yes & No \\
\hline Costa Crociere & Italy & Large & Private company & Listed & $\begin{array}{l}\text { Tourism/Leis } \\
\text { ure }\end{array}$ & Yes & Yes \\
\hline Credito Valtellinese & Italy & Large & Private company & Listed & $\begin{array}{l}\text { Financial } \\
\text { Services }\end{array}$ & Yes & Yes \\
\hline Ecodom & Italy & SME & Partnership & Non-listed & $\begin{array}{l}\text { Waste } \\
\text { Management }\end{array}$ & Yes & No \\
\hline Edipower & Italy & Large & Private company & Listed & Energy & Yes & No \\
\hline Edison & Italy & Large & Private company & Listed & Energy & Yes & Yes \\
\hline Egea & Italy & Large & Private company & Non-listed & Energy & No & No \\
\hline Enel & Italy & MNE & Private company & Listed & $\begin{array}{l}\text { Energy } \\
\text { Utilities }\end{array}$ & Yes & Yes \\
\hline Engineering & Italy & Large & Private company & Listed & Other & No & No \\
\hline Eni S.P.A. & Italy & MNE & Private company & Listed & Energy & Yes & Yes \\
\hline ENPAM & Italy & SME & $\begin{array}{l}\text { Non-profit } \\
\text { organization }\end{array}$ & $\begin{array}{l}\text { Not } \\
\text { applicable }\end{array}$ & $\begin{array}{l}\text { Non-Profit / } \\
\text { Services }\end{array}$ & Yes & No \\
\hline Epta Group & Italy & MNE & Private company & Non-listed & $\begin{array}{l}\text { Consumer } \\
\text { Durables }\end{array}$ & Yes & No \\
\hline ERG (Gruppo ERG) & Italy & Large & Private company & Listed & Energy & Yes & Yes \\
\hline ESPRINET & Italy & Large & Private company & Listed & Other & Yes & No \\
\hline Etica Sgr S.p.A. & Italy & SME & Private company & Non-listed & $\begin{array}{l}\text { Financial } \\
\text { Services }\end{array}$ & Yes & No \\
\hline Eurosuole & Italy & SME & Private company & Non-listed & $\begin{array}{l}\text { Textiles and } \\
\text { Apparel }\end{array}$ & No & No \\
\hline FASTWEB & Italy & Large & Subsidiary & Non-listed & $\begin{array}{l}\text { Telecommuni } \\
\text { cations }\end{array}$ & Yes & Yes \\
\hline
\end{tabular}




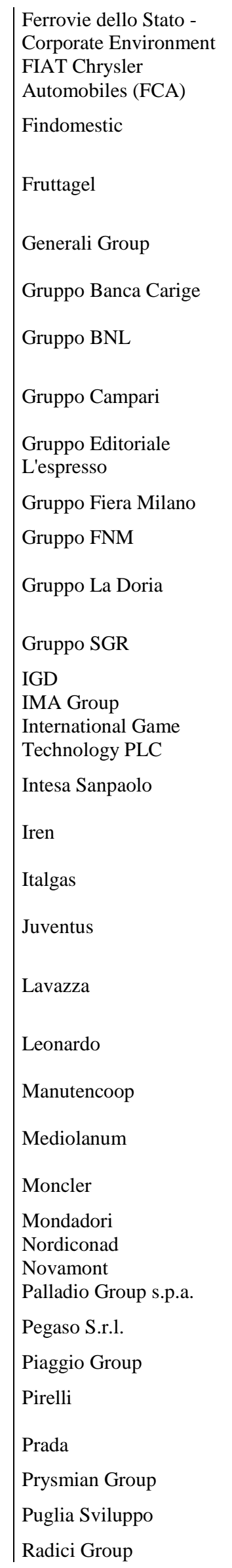

\begin{tabular}{|c|c|c|c|c|c|c|}
\hline Italy & Large & $\begin{array}{l}\text { State-owned } \\
\text { company }\end{array}$ & Non-listed & Railroad & Yes & Yes \\
\hline Italy & MNE & Private company & Listed & Automotive & Yes & Yes \\
\hline Italy & Large & Private company & Non-listed & $\begin{array}{l}\text { Financial } \\
\text { Services }\end{array}$ & No & No \\
\hline Italy & Large & Cooperative & Non-listed & $\begin{array}{l}\text { Food and } \\
\text { Beverage } \\
\text { Products }\end{array}$ & No & No \\
\hline Italy & MNE & Private company & Listed & $\begin{array}{l}\text { Financial } \\
\text { Services }\end{array}$ & No & Yes \\
\hline Italy & Large & Private company & Listed & $\begin{array}{l}\text { Financial } \\
\text { Services }\end{array}$ & No & No \\
\hline Italy & Large & Private company & Non-listed & $\begin{array}{l}\text { Financial } \\
\text { Services }\end{array}$ & No & No \\
\hline Italy & MNE & Private company & Listed & $\begin{array}{l}\text { Food and } \\
\text { Beverage } \\
\text { Products }\end{array}$ & No & No \\
\hline Italy & Large & Private company & Listed & Media & Yes & No \\
\hline Italy & Large & $\begin{array}{l}\text { State-owned } \\
\text { company }\end{array}$ & Listed & Other & No & No \\
\hline Italy & Large & Private company & Listed & $\begin{array}{l}\text { Railroad } \\
\text { Food and }\end{array}$ & Yes & Yes \\
\hline Italy & Large & Private company & Non-listed & $\begin{array}{l}\text { Beverage } \\
\text { Products }\end{array}$ & No & Yes \\
\hline Italy & SME & Private company & Non-listed & $\begin{array}{l}\text { Energy } \\
\text { Utilities }\end{array}$ & Yes & No \\
\hline Italy & Large & Private company & Listed & Real Estate & No & No \\
\hline Italy & MNE & Private company & Listed & Other & No & No \\
\hline Italy & Large & Private company & Listed & Other & Yes & No \\
\hline Italy & Large & Private company & Listed & $\begin{array}{l}\text { Financial } \\
\text { Services }\end{array}$ & Yes & Yes \\
\hline Italy & Large & Private company & Listed & $\begin{array}{l}\text { Energy } \\
\text { Utilities }\end{array}$ & Yes & Yes \\
\hline Italy & Large & Private company & Listed & $\begin{array}{l}\text { Energy } \\
\text { Utilities }\end{array}$ & Yes & No \\
\hline Italy & Large & Private company & Listed & $\begin{array}{l}\text { Tourism/Leis } \\
\text { ure }\end{array}$ & Yes & No \\
\hline Italy & Large & $\begin{array}{l}\text { State-owned } \\
\text { company }\end{array}$ & Listed & $\begin{array}{l}\text { Food and } \\
\text { Beverage } \\
\text { Products }\end{array}$ & Yes & No \\
\hline Italy & MNE & Private company & Listed & $\begin{array}{l}\text { Conglomerate } \\
\mathrm{S}\end{array}$ & Yes & Yes \\
\hline Italy & Large & Private company & Non-listed & $\begin{array}{l}\text { Commercial } \\
\text { Services }\end{array}$ & Yes & No \\
\hline Italy & Large & Private company & Listed & $\begin{array}{l}\text { Financial } \\
\text { Services }\end{array}$ & No & No \\
\hline Italy & Large & Private company & Listed & $\begin{array}{l}\text { Textiles and } \\
\text { Apparel }\end{array}$ & Yes & No \\
\hline Italy & Large & Private company & Listed & Media & Yes & Yes \\
\hline Italy & Large & Cooperative & Non-listed & Retailers & No & No \\
\hline Italy & SME & Private company & Listed & Chemicals & Yes & Yes \\
\hline Italy & Large & Private company & Non-listed & Other & Yes & No \\
\hline Italy & SME & Private company & Non-listed & $\begin{array}{l}\text { Healthcare } \\
\text { Products }\end{array}$ & No & No \\
\hline Italy & Large & Private company & Listed & Automotive & Yes & No \\
\hline Italy & MNE & Private company & Listed & $\begin{array}{l}\text { Conglomerate } \\
\mathrm{s}\end{array}$ & Yes & Yes \\
\hline Italy & MNE & Private company & Listed & $\begin{array}{l}\text { Textiles and } \\
\text { Apparel }\end{array}$ & No & No \\
\hline Italy & MNE & Private company & Listed & Equipment & Yes & No \\
\hline Italy & SME & $\begin{array}{l}\text { State-owned } \\
\text { company }\end{array}$ & Non-listed & $\begin{array}{l}\text { Financial } \\
\text { Services }\end{array}$ & Yes & No \\
\hline Italy & Large & Private company & Non-listed & Chemicals & Yes & No \\
\hline
\end{tabular}




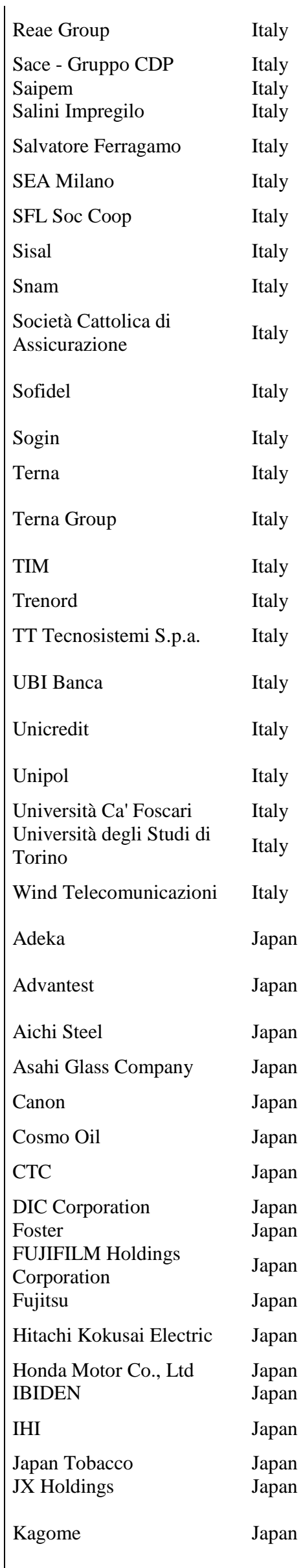

$\begin{array}{lll}\text { MNE } & \text { Private company } & \text { Listed } \\ \text { Large } & \text { Private company } & \text { Non-listed } \\ \text { Large } & \text { Private company } & \text { Listed } \\ \text { MNE } & \text { Private company } & \text { Listed } \\ \text { Large } & \text { Private company } & \text { Listed }\end{array}$

Financial

Services No

No

Other Yes No

Energy Yes $\quad$ Yes

Construction Yes Yes

Textiles and Yes Yes

Large Private company Non-listed Aviation No

Large

Large

Cooperative Non-listed

Services No

No

Large

Private company Listed

Other

Energy

Utilities

Large Private company Listed

Other

Forest and

Large Private company Non-listed

Paper

Large Private company Non-listed

Products

Large Private company Listed

Energy

Energy

Utilities

Large Private company Listed

Energy

Utilities

Large Private company Listed

Telecommuni

cations Yes

Large Private company Non-listed

SME Private company Listed

Other Yes

Technology No

Hardware

$\begin{array}{ll}\text { Financial } & \text { Yes } \\ \text { Services } & \end{array}$

Large Private company Listed

Large Private company Listed

Financial

Services

Large Private company Listed

Financial

Services No

Large Public institution Non-listed

Universities No

Large Public institution Non-listed

Universities No

No

Large Subsidiary Non-listed

Telecommuni No

cations

Large Private company Non-listed

Healthcare

Products No

Technology No

MNE Private company Listed

Hardware

Large Subsidiary

Listed

Metal

Products

Chemicals Yes

MNE Private company Listed

Technology

MNE Subsidiary

Non-listed

MNE Private company Listed

Hardware No

Energy Yes

Technology

Hardware

MNE Private company Listed

Chemicals Yes

Equipment No

Conglomerate Yes

$\mathrm{s}$

Large Private company Listed

MNE Private company Listed

Equipment Yes

Technology

Hardware

Automotive Yes

Equipment No

Energy

Utilities

Tobacco

Energy

Food and

Beverage

Products

No

Yes

Yes

No

Yes

Yes

No

Yes

Yes

Yes

No

No

No

Yes

No

No

Yes

No

No

No

No

No

No

Yes

No

No

No

No

Yes

No

Yes

No

MNE Private company Listed

MNE Private company Listed

No

Yes

No 


\begin{tabular}{|c|c|c|c|c|c|c|c|}
\hline Kao Corporation & Japan & MNE & Private company & Listed & Chemicals & Yes & No \\
\hline Kddi Corp. & Japan & Large & Private company & Listed & $\begin{array}{l}\text { Telecommuni } \\
\text { cations }\end{array}$ & Yes & No \\
\hline Kikkoman & Japan & MNE & Private company & Listed & $\begin{array}{l}\text { Food and } \\
\text { Beverage } \\
\text { Products }\end{array}$ & No & No \\
\hline Komatsu & Japan & MNE & Private company & Listed & Other & No & No \\
\hline Konica Minolta Group & Japan & MNE & Private company & Listed & $\begin{array}{l}\text { Technology } \\
\text { Hardware }\end{array}$ & Yes & No \\
\hline Kyocera & Japan & MNE & Private company & Listed & Equipment & No & No \\
\hline LIXIL Group & Japan & MNE & Private company & Listed & Construction & Yes & Yes \\
\hline Mazda & Japan & Large & Private company & Listed & Automotive & Yes & Yes \\
\hline Mitsubishi Estate & Japan & MNE & Private company & Listed & Real Estate & No & No \\
\hline Mitsui Chemicals & Japan & MNE & Private company & listed & Chemicals & No & No \\
\hline Mitsui \& Co. & Japan & MNE & Private company & Listed & Other & No & No \\
\hline Mitsui Kinzoko & Japan & Large & Subsidiary & Non-listed & $\begin{array}{l}\text { Metal } \\
\text { Products }\end{array}$ & No & No \\
\hline NEC Corporation & Japan & MNE & Private company & Listed & $\begin{array}{l}\text { Technology } \\
\text { Hardware }\end{array}$ & Yes & Yes \\
\hline NGK Insulators & Japan & MNE & Private company & Listed & Chemicals & No & No \\
\hline Nikon & Japan & MNE & Private company & Listed & $\begin{array}{l}\text { Technology } \\
\text { Hardware }\end{array}$ & Yes & No \\
\hline Nissan & Japan & MNE & Private company & Listed & Automotive & Yes & No \\
\hline Nitto Denko Corporation & Japan & Large & Private company & Listed & Chemicals & No & No \\
\hline Sekisui Chemical & Japan & MNE & Private company & Listed & Chemicals & Yes & Yes \\
\hline Sekisui House & Japan & Large & Private company & Listed & Real Estate & Yes & Yes \\
\hline Shiseido & Japan & MNE & Private company & Listed & $\begin{array}{l}\text { Consumer } \\
\text { Durables }\end{array}$ & No & Yes \\
\hline Sumitomo Bakelite & Japan & MNE & Private company & Listed & Chemicals & Yes & Yes \\
\hline $\begin{array}{l}\text { Sumitomo Electric } \\
\text { Industries }\end{array}$ & Japan & MNE & Private company & Listed & $\begin{array}{l}\text { Technology } \\
\text { Hardware }\end{array}$ & Yes & Yes \\
\hline Sumitomo Forestry & Japan & MNE & Subsidiary & Listed & Real Estate & Yes & Yes \\
\hline $\begin{array}{l}\text { Sumitomo Trust and } \\
\text { Banking }\end{array}$ & Japan & MNE & Private company & Listed & $\begin{array}{l}\text { Financial } \\
\text { Services }\end{array}$ & No & Yes \\
\hline Sysmex & Japan & MNE & Private company & Listed & Equipment & No & Yes \\
\hline T.RAD & Japan & MNE & Private company & Listed & Equipment & No & Yes \\
\hline Tsumura \& Co. & Japan & MNE & Private company & Listed & Chemicals & Yes & Yes \\
\hline
\end{tabular}

